\title{
Novel methylotrophic isolates from lake sediment, description of Methylotenera versatilis sp. nov. and emended description of the genus Methylotenera
}

\author{
Marina G. Kalyuzhnaya, ${ }^{1}$ David A. C. Beck, ${ }^{2,3}$ Alexey Vorobev, ${ }^{3}$ \\ Nicole Smalley, ${ }^{1}$ Dennis D. Kunkel, ${ }^{4}$ Mary E. Lidstrom ${ }^{1,3}$ \\ and Ludmila Chistoserdova ${ }^{3}$ \\ ${ }^{1}$ Department of Microbiology, University of Washington, Seattle, WA, USA \\ ${ }^{2}$ eScience Institute, University of Washington, Seattle, WA, USA \\ ${ }^{3}$ Department of Chemical Engineering, University of Washington, Seattle, WA, USA \\ ${ }^{4}$ Dennis Kunkel Microscopy, Inc., Box 2008 Kailua, HI 96734, USA
}

Correspondence Ludmila Chistoserdova milachis@u.washington.edu
Methylotrophic bacteria belonging to the family of Methylophilaceae are widespread across a variety of terrestrial, freshwater and estuary ecosystems (Jenkins \& Jones, 1987; Govorukhina \& Trotsenko, 1991; Doronina et al., 2005; Kalyuzhnaya et al., 2006; Giovannoni et al., 2008). We have recently demonstrated that Methylophilaceae, and especially species of the genus Methylotenera, are important functional types in environmental cycling of $\mathrm{C} 1$ compounds in Lake Washington sediment (Kalyuzhnaya et al., 2008b, 2009). Although a number of closely related Methylotenera strains (95-97\% 16S rRNA similarities) appear to be present in this ecosystem, only one Methylotenera strain has been

Abbreviation: RuMP, ribulose monophosphate.

The GenBank/EMBL/DDBJ accession number for the complete genome sequence of Methylotenera versatilis $301^{\top}$ is CP002056.

Two supplementary figures are available with the online version of this paper. formally described so far (Kalyuzhnaya et al., 2006). In this study, a dilution-plating approach was used that resulted in isolation of three novel strains $\left(301^{\mathrm{T}}, 30 \mathrm{~S}\right.$ and SIP3-4) of the family Methylophilaceae. Two of these strains were characterized in detail, in terms of their phenotypic, physiological, biochemical and genomic properties.

Lake Washington sediment samples were collected as described previously (Kalyuzhnaya et al., 2004). To isolate strains $301^{\mathrm{T}}$ and $30 \mathrm{~S}, 1 \mathrm{ml}$ aliquots of sediment samples were mixed with $9 \mathrm{ml}$ filtered lake water, and serial dilutions were plated onto plates containing lake water-based medium solidified with agar (2\%; Difco) supplemented with $5 \mathrm{mM}$ methylamine. After 2 weeks incubation at room temperature, individual colonies were restreaked onto fresh agar plates. Two types of colonies were observed: large opaque milky-white (named strain $301^{\mathrm{T}}$ ) and small translucent (named strain 30S). Each type of colony was plated 
separately and pure cultures of strains $301^{\mathrm{T}}$ and $30 \mathrm{~S}$ were obtained after six passages on solid media.

Strain SIP3-4 was isolated from a methanol enrichment culture. A sample of lake sediment $(3 \mathrm{ml})$ was mixed with $50 \mathrm{ml}$ lake water supplemented with methanol $(0.1 \%)$ and nitrate $(10 \mathrm{mM})$. The enrichment culture was incubated for 2 days at $30{ }^{\circ} \mathrm{C}$ and reinoculated (1/100) into $50 \mathrm{ml}$ of the same culture medium. A pure culture of isolate SIP3-4 was obtained by serial dilutions of a third passage of the enrichment culture.

Purity of the cultures was monitored by microscopy, $16 \mathrm{~S}$ rRNA gene amplification and sequencing, and was ultimately confirmed by complete genome sequencing for strains $301^{\mathrm{T}}$ and SIP3-4 (the genomes will be described in a separate publication). A pure culture of strain SIP3-4 was routinely maintained on a basal salts medium supplemented with methanol or methylamine (Harder et al., 1973). Pure cultures of strains $301^{\mathrm{T}}$ and $30 \mathrm{~S}$ were routinely maintained on a diluted $(0.2 \times)$ basal salts medium supplemented with $0.1 \%$ methylamine and a vitamin stock solution (Kalyuzhnaya et al., 2008a). Cells of strain SIP3-4 were prepared for scanning electron microscopy as described previously (Kalyuzhnaya et al., 2006) and these were viewed using an FEI Sirion scanning electron microscope (http:// depts.washington.edu/ntuf/facility/sirion_sem.php). Cells of strain $301^{\mathrm{T}}$ were prepared as described in Supplementary material (available in IJSEM Online) and viewed using a Hitachi s800 field emission scanning electron microscope at the University of Hawaii (http://www5.pbrc.hawaii.edu/ bemf/site/). For long-term storage at $-80{ }^{\circ} \mathrm{C}$, cells were suspended in the basal salts media given above and supplemented with $10 \%$ DMSO.

Phenotypic characterization of the isolates was carried out essentially as described previously (Smibert \& Krieg, 1994). Sensitivity to antibiotics was examined by spreading cells onto mineral medium agar plates and placing BBL SensiDiscs (BD Diagnostic Systems) on them; the effect of antibiotics was assessed after 2 weeks incubation. Cellular fatty acid (phospholipid fatty acid) analysis was carried out by Microbial Insights, Inc. (Rockford, TN, USA; http:// www.microbe.com/). Chromosomal DNA was extracted and purified as described previously (Kalyuzhnaya et al., 2006). Whole genome sequencing, genome assembly and gene annotation were carried out by the Department of Energy Joint Genome Institute (Walnut Creek, CA, USA; http://www.jgi.doe.gov/) essentially as described previously (Lykidis et al., 2010). 16S rRNA gene sequences were aligned using the program CLUSTAL w (Higgins et al., 1996) and phylogenetic analysis was carried out using the PHYLIP package (Felsenstein, 2004).

Cells of strain $301^{\mathrm{T}}$ were oval or rod-shaped $(1.0 \pm 0.2$ $\times 0.5 \pm 0.1 \mu \mathrm{m}$ in size), sometimes forming long filaments (up to $10-15 \mu \mathrm{m}$ ) (Fig. 1a). Cells grown on methylaminesupplemented solid medium for 3 days were non-motile; however, genome analysis revealed that the strain possessed genes for flagellum biosynthesis similar to the ones present
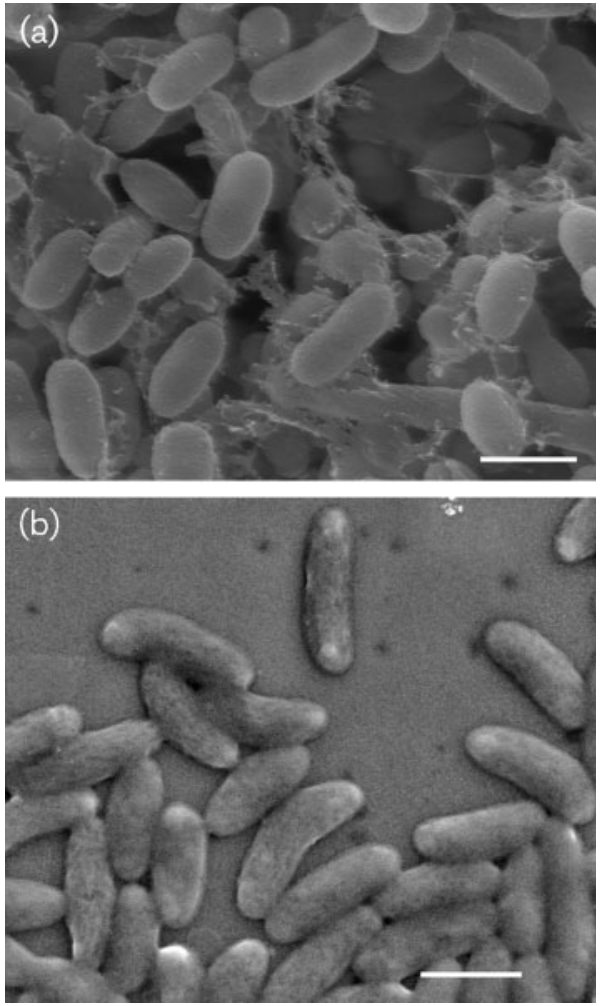

Fig. 1. Scanning electron micrographs of cells of strains $301^{\top}$ (a) and SIP3-4 (b). Bars, $1 \mu \mathrm{m}$.

in the genomes of motile members of the family Methylophilaceae (Chistoserdova et al., 2007; Kalyuzhnaya et al., 2008b). Colonies of strain $301^{\mathrm{T}}$ were white (slightly yellowish in old cultures), mucoid, undulate, circular, convex, viscous and up to $5 \mathrm{~mm}$ in diameter. The isolate grew well on solid media but not in liquid culture. Only cultures incubated without shaking showed some growth. Strain $301^{\mathrm{T}}$ grew well on methylamine, fructose and betaine. Weak growth was observed on solid agar medium supplemented with methanol, ethanol or pyruvate. In addition, the isolate could grow on a complex medium containing $0.5 \%$ bacto-peptone, $0.05 \%$ yeast extract and vitamins (ATCC medium 36; http://www.lgcstandards-atcc. org/). Arabinose, formate, acetate, succinate, malate, mannitol, methionine, valine, threonine, vanillin, phenol, DMSO and trimethylamine did not support growth. Ammonium, nitrate and urea were used as sources of nitrogen. $\mathrm{pH}$ and temperature optima of the isolate were tested on solid basal media supplemented with $0.1 \%$ methylamine. Growth occurred at $\mathrm{pH} 4.2-8.0$ and $4-30{ }^{\circ} \mathrm{C}$, with optimum growth at $\mathrm{pH} 5.8-6.5$ and $18-21^{\circ} \mathrm{C}$.

Cells of strain $30 \mathrm{~S}$ were motile and oval-shaped $(0.8 \pm 0.2 \times 0.6 \pm 0.1 \mu \mathrm{m}$ in size $)$. On agar plates supplemented with methylamine, the strain formed small, smooth, circular, slightly greenish, translucent colonies with butyrous texture. Strain $30 \mathrm{~S}$ was able to utilize methylamine and fructose but not betaine. With respect to other sources of 
carbon and nitrogen as well as temperature and $\mathrm{pH}$ optima, strain $30 \mathrm{~S}$ behaved like strain $301^{\mathrm{T}}$. The $16 \mathrm{~S}$ rRNA gene and fragments of the $m d g A$ ( $N$-methylglutamate dehydrogenase, small subunit), fae (formaldehyde-activating enzyme) and soxA (sarcosine oxidase) genes of this strain were identical to those of strain $301^{\mathrm{T}}$, indicating a very close relatedness between the two isolates. Thus, only strain $301^{\mathrm{T}}$ was further characterized.

Cells of strain SIP3-4 were motile, slightly curved rods, $1.4 \pm 0.4 \times 0.3 \pm 0.1 \mu \mathrm{m}$ in size (Fig. 1b). During growth on solid media supplemented with methanol or methylamine, the isolate formed circular, smooth colonies with entire margins, $1-2 \mathrm{~mm}$ in diameter and caramel in colour. The isolate grew well in liquid culture, with doubling times of $3.5 \mathrm{~h}$ on methanol, $17 \mathrm{~h}$ on methylamine and $15 \mathrm{~h}$ on glucose. Fructose, arabinose, formate, acetate, ethanol, pyruvate, succinate, malate, mannitol, methionine, valine, threonine, betaine, vanillin, phenol, DMSO and trimethylamine did not support growth. $\mathrm{pH}$ and temperature optima of strain SIP3-4 were tested in liquid mineral media supplemented with $0.1 \%$ methanol. Growth occurred at $\mathrm{pH} 4.2-8.0$ and $9-37{ }^{\circ} \mathrm{C}$, with optimum growth at $\mathrm{pH} 6.5$ and $30{ }^{\circ} \mathrm{C}$.

All isolates were resistant to penicillin $(10 \mathrm{U})$ and sensitive to kanamycin $(30 \mu \mathrm{g})$, ampicillin $(10 \mu \mathrm{g})$, streptomycin $(100 \mu \mathrm{g})$, neomycin $(30 \mu \mathrm{g})$ and erythromycin $(15 \mu \mathrm{g})$.

Cell extracts were prepared and enzyme activities were determined as described previously (Miller et al., 2005). Enzyme activities were monitored spectrophotometrically by observing absorbance at either $340 \mathrm{~nm}$ (extinction coefficient of $\mathrm{NADH}=6.22 \times 10^{3} \mathrm{~mol} \mathrm{l}^{-1} \mathrm{~cm}^{-1}$ ) or $600 \mathrm{~nm}$ (extinction coefficient of DCPIP $=8.31 \times 10^{3} \mathrm{~mol} \mathrm{l}^{-1} \mathrm{~cm}^{-1}$; Bergmeyer et al., 1974). The novel isolates were similar to other representatives of the family Methylophilaceae in that they possessed high activity of a key enzyme of the ribulose monophosphate (RuMP) cycle, hexulose phosphate synthase $\left.\left[200 \pm 20 \mathrm{nmol} \mathrm{min}{ }^{-1} \text { (mg protein }\right)^{-1}\right]$ and lacked activities of key enzymes of the serine cycle (serine glyoxylate aminotransferase and hydroxypyruvate reductase). Whole genome sequence analyses confirmed that strains SIP3-4

Table 1. Characteristics of the novel strains and related bacteria of the family Methylophilaceae

Taxa: 1, strain $301^{\mathrm{T}} ; 2$, Methylotenera mobilis $\mathrm{JLW}^{\mathrm{T}}$; 3, Methylobacillus; 4, SIP3-4; 5, Methylovorus; 6, Methylophilus; 7, Methylophilales bacterium HTCC2181. NR, Not reported; ND, not determined; TR, trace; $+/-$, variable depending on strain.

\begin{tabular}{|c|c|c|c|c|c|c|c|}
\hline Character & 1 & 2 & $3^{*} \dagger$ & 4 & $5 \dagger \ddagger$ & $6^{*} \dagger$ & $7 \S$ \\
\hline Genome size $(\mathrm{Mb})$ & 3.06 & 2.55 & $2.97 I I$ & 3.08 & $\mathrm{NR}$ & NR & 1.30 \\
\hline DNA G $+\mathrm{C}$ content $(\mathrm{mol} \%)$ & 42.6 & 45.5 & $53-62(55.71 I)$ & 54.6 & $56-58$ & $50-53$ & 37.9 \\
\hline Plasmids & - & - & -11 & 2 & NR & NR & - \\
\hline Copies of rRNA gene cluster & 3 & 2 & 211 & 2 & NR & $\mathrm{NR}$ & 1 \\
\hline $\begin{array}{l}\text { Methylamine dehydrogenase } \\
(\text { mauFBEDACJG) }\end{array}$ & - & + & +11 & - & $+1-$ & $+1-$ & - \\
\hline $\begin{array}{l}\text { NMG pathway } \\
(m g d A B C D g m a s A m g s A B C)\end{array}$ & + & - & + & + & $+1-$ & $+1-$ & - \\
\hline Methanol dehydrogenase ( $m x a F I)$ & - & - & + & + & + & + & - \\
\hline RuMP pathway & + & + & + & + & + & + & + \\
\hline Complete TCA cycle & - & - & - & - & - & - & - \\
\hline \multicolumn{8}{|l|}{ Fatty acids: } \\
\hline $\mathrm{C}_{16: 0}$ & 38 & 32 & $41-43$ & 49 & $47-49$ & $32-48$ & NR \\
\hline $\mathrm{C}_{16: 1} \omega 7 c$ & 56 & 66 & $32-36$ & 45 & $32-35$ & $46-53$ & $\mathrm{NR}$ \\
\hline $\mathrm{C}_{16: 1} \omega 7 t$ & 2.2 & 0 & $3-8$ & 0.2 & $2-3$ & $4-12$ & NR \\
\hline cyclo- $\mathrm{C}_{17: 0}$ & $\mathrm{TR}$ & $\mathrm{TR}$ & $5-8$ & 2.7 & $10-13$ & $1-2$ & NR \\
\hline $\mathrm{C}_{18: 0}$ & 2 & 0.3 & $0.7-1.2$ & 0.5 & $0.6-0.7$ & $0.6-4.0$ & $\mathrm{NR}$ \\
\hline $\mathrm{C}_{18: 1} \omega 7 c$ & 0.4 & 0.7 & 5 & 1.7 & $1-2$ & $0.7-2.0$ & $\mathrm{NR}$ \\
\hline \multicolumn{8}{|l|}{$\begin{array}{l}\text { DNA-DNA identity ( } \% \text { of genes with } \\
\text { identity } \geqslant 70 \% \text { ): }\end{array}$} \\
\hline $301^{\mathrm{T}}$ & 100 & 41.3 & 11.3 & 16.2 & ND & ND & 3.2 \\
\hline SIP3-4 & & 20.6 & 33.9 & 100 & ND & ND & 2.6 \\
\hline $\mathrm{JLW}^{\mathrm{T}}$ & & 100 & 15.4 & & ND & ND & 5.0 \\
\hline Methylobacillus flagellatus $\mathrm{KT}^{\mathrm{T}} \|$ & & & 100 & & ND & ND & 2.0 \\
\hline
\end{tabular}

${ }^{\star}$ Data from Jenkins \& Jones (1987).

$\dagger$ Data from Govorukhina \& Trotsenko (1991).

¥Data from Doronina et al. (2005).

§Data from Giovannoni et al. (2008).

IIData from Chistoserdova et al. (2007). 
and $301^{\mathrm{T}}$ possessed all the genes for the RuMP cycle and lacked key genes of the serine cycle (Table 1). Neither $\alpha$-ketoglutarate dehydrogenase nor the glyoxylate shunt genes/ enzymes were present.

Strain SIP3-4 displayed high methanol dehydrogenase activity $\left[300 \pm 30 \mathrm{nmol} \mathrm{min}{ }^{-1}(\mathrm{mg} \text { protein })^{-1}\right]$ and genome analysis (http://genome.jgi-psf.org/) showed that it possessed the typical mxaFJGI gene cluster encoding the subunits of methanol dehydrogenase and the associated cytochrome $c$. Strain $301^{\mathrm{T}}$ lacked mxaFJGI in its genome (data not shown). Tests for methylamine dehydrogenase in cells grown in methylamine $(0.1 \%, \mathrm{w} / \mathrm{v})$ were negative for both strains. Accordingly, the genomes lacked recognizable homologues of the mau genes (mauFBEDAC). However, both strains were positive for $\mathrm{N}$-methylglutamate dehydrogenase activity, a key enzyme of the $N$-methylglutamate pathway $\left[75 \pm 10\right.$ and $50 \pm 10 \mathrm{nmol} \mathrm{min}{ }^{-1}(\mathrm{mg} \text { protein })^{-1}$ for strains $301^{\mathrm{T}}$ and SIP3-4, respectively]. Gene clusters highly similar to the ones described recently, encoding $\mathrm{N}$ methylglutamate dehydrogenase, $\mathrm{N}$-methylglutamate synthase and $\gamma$-glutamyl methylamide synthase (Latypova et al., 2010), were identified in the genomes of isolates $301^{\mathrm{T}}$ and SIP3-4 (data not shown).

For fatty acid analysis, the isolates were grown on agar plates supplemented with methylamine. In general, the fatty acid profiles of the cultures were typical of other representatives of the family Methylophilaceae (Table 1), the major fatty acids being $\mathrm{C}_{16: 1} \omega 7 c$ and $\mathrm{C}_{16: 0}$. As with other methylotrophs of the Methylobacillus/Methylovorus subgroup, strain SIP3-4 possessed cyclo- $\mathrm{C}_{17: 0}$ (approx. $3 \%)$. Only trace amounts of the $\mathrm{C}_{17}$ fatty acids were detected in strain $301^{\mathrm{T}}$, which is typical for representatives of the Methylophilus/Methylotenera subgroup.

Based on genome sequence data, DNA G $+\mathrm{C}$ contents of the novel isolates were $42.6 \mathrm{~mol} \%$ (strain $301^{\mathrm{T}}$ ) and $54.6 \mathrm{~mol} \%$ (strain SIP3-4). 16S rRNA gene phylogeny is depicted in Fig. 2. Of the formally characterized bacteria, the novel isolates were related, as expected, to methylotrophs of the family Methylophilaceae (Jenkins \& Jones, 1987; Doronina et al., 2005) with strain SIP3-4 being most closely related to the type strains of Methylovorus glucosotrophus and Methylovorus mays ( $99.0 \%$ sequence similarity) and strain $301^{\mathrm{T}}$ being most closely related to the type strain of Methylotenera mobilis ( $96.6 \%$ sequence similarity).

Genome relatedness of the novel isolates to each other and to the most related organisms with sequenced genomes was investigated via in silico DNA-DNA hybridization. The details of this method are described in the Supplementary material (available in IJSEM Online). Only $41.3 \%$ of the genes of strain $301^{\mathrm{T}}$ were found to have $\geqslant 70 \%$ identity

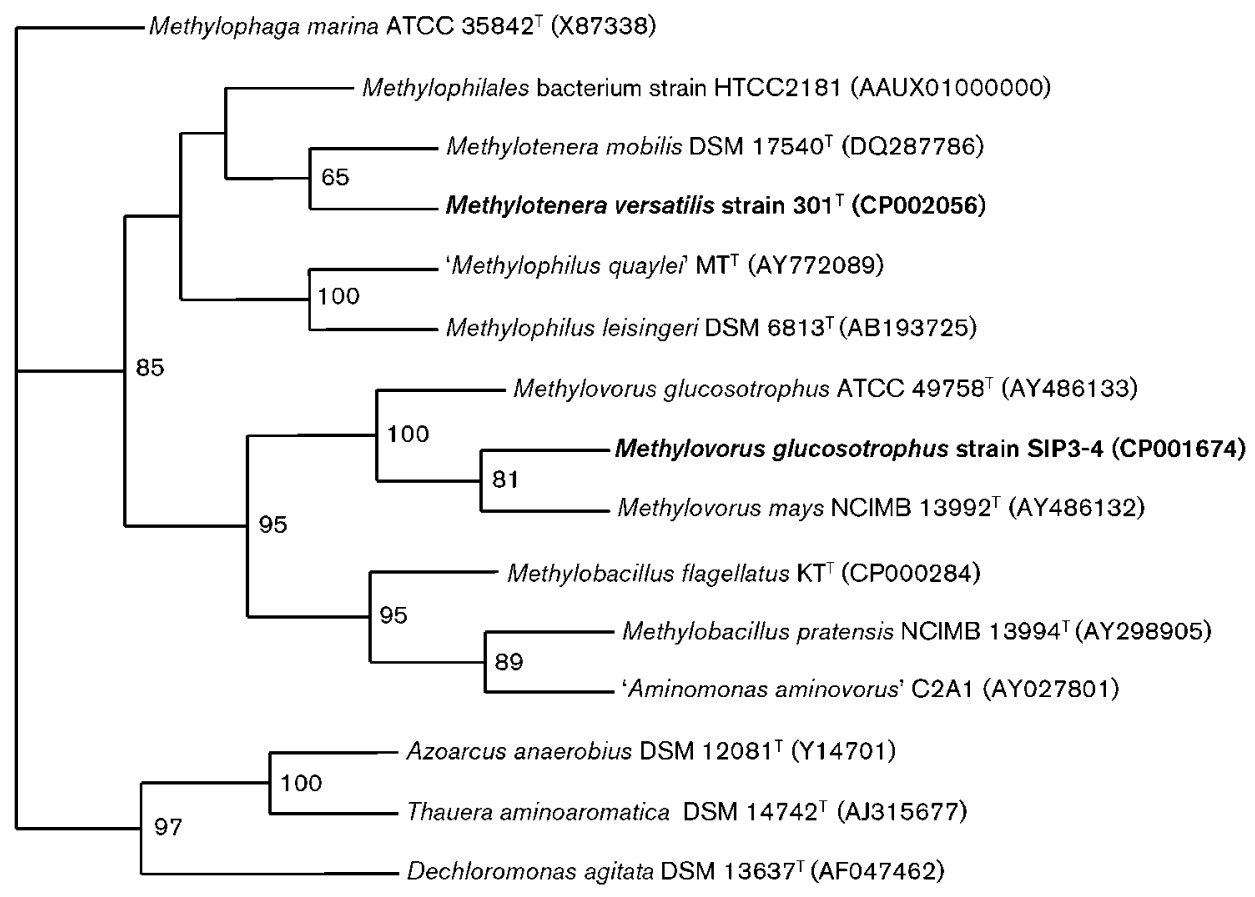

Fig. 2. Phylogenetic tree showing the relationship of isolates $301^{\top}$ and SIP3-4 to representatives of the families Methylophilaceae and Rhodocyclaceae within the betaproteobacteria, based upon 16S rRNA gene sequences. The 16S rRNA gene sequence of Methylophaga marina ATCC $35842^{\top}$, a gammaproteobacterium, was used as outgroup. The tree was constructed for nearly full-length 16S rRNA gene sequences (1368-1371 bp) using the maximum-likelihood method (DNAML, PHYLIP version 3.69). Bootstrap analysis was performed with 1000 replicates. Bootstrap values over $50 \%$ are shown. Strain collection accession numbers and GenBank accession numbers (in parentheses) are shown. 
with the genes of the type strain Methylotenera mobilis $\mathrm{JLW} 8^{\mathrm{T}}$. These data, along with physiological tests, suggest that strain $301^{\mathrm{T}}$ represents a novel species within the genus Methylotenera, for which the name Methylotenera versatilis is proposed, in light of the versatile trophic abilities of the isolate.

Strain SIP3-4 was distantly related to both Methylobacillus flagellatus $\mathrm{KT}^{\mathrm{T}}$ and Methylotenera mobilis $\mathrm{JLW}^{\mathrm{T}}$, with $33.9 \%$ and $20.6 \%$ of genes sharing $\geqslant 70 \%$ identity, respectively. As no genome sequence for a Methylovorus representative is available, the phylogenetic affiliation of strain SIP3-4 was determined based on phenotypic characteristics and 16S rRNA gene phylogeny, and the strain was assigned to the species Methylovorus glucosotrophus. The characteristics of the strain fit with the current description of the genus and the species (Doronina et al., 2005).

\section{Emended description of the genus Methylotenera}

Methylotenera [Me.thy.lo.te'ner.a. N.L. methylum (from French méthyle, back-formation from French méthylène, coined from Gr. n. methu wine and Gr. n. hulê wood) the methyl group radical; N.L. pref. methylo- pertaining to the methyl radical; L. fem. adj. tenera delicate; N.L. fem. n. Methylotenera a methyl group-oxidizing delicate bacterium].

Gram-negative rods. Some strains are motile. Do not form resting bodies and multiply by binary fission. Utilize methylamine. In addition, may utilize methanol, betaine, fructose, ethanol and pyruvate as sole sources of carbon and energy. Some strains are positive for urease and nitrate reduction. Oxidize methylamine via methylamine dehydrogenase or via $N$-methylglutamate pathway and assimilate $\mathrm{C} 1$ units via the RuMP pathway. The major fatty acids are $\mathrm{C}_{16: 1} \omega 7 c$ and $\mathrm{C}_{16: 0}$. The DNA $\mathrm{G}+\mathrm{C}$ content is in the range $42.6-45.5 \mathrm{~mol} \%$. Type species is Methylotenera mobilis.

\section{Description of Methylotenera versatilis sp. nov.}

Methylotenera versatilis (ver.sa'ti.lis. L. fem. adj. versatilis versatile).

General characteristics are as for the genus. Facultative methylotroph, grows at $\mathrm{pH}$ 4.2-8.0, with optimum growth at pH 5.8-6.5. Temperature optimum is $18-21{ }^{\circ} \mathrm{C}$. Cells are oval or rod-shaped, $1.0 \pm 0.2 \times 0.5 \pm 0.2 \mu \mathrm{m}$ in size, and may form small cell clusters. In addition to methylamine, may utilize fructose, betaine, methanol, pyruvate and ethanol. Grows on a complex medium containing $0.5 \%$ bacto-peptone, $0.05 \%$ yeast extract and vitamins. Ammonium, nitrate and urea may serve as sources of nitrogen. The major fatty acids are $\mathrm{C}_{16: 1} \omega 7 c$ and $\mathrm{C}_{16: 0 \text {. }}$

The type strain is $301^{\mathrm{T}}\left(=\mathrm{VKM} \mathrm{B}-2679^{\mathrm{T}}=\mathrm{JCM} 17579^{\mathrm{T}}\right)$, isolated from sediment from freshwater Lake Washington (USA). The DNA G $+\mathrm{C}$ content of the type strain is $42.6 \mathrm{~mol} \%$.

\section{Acknowledgements}

This work was supported by the NSF (grants MCB-00604269 and MCB-0842686). The authors thank Sarah McQuaide and Chad Goodwin for SEM images of cell samples.

\section{References}

Bergmeyer, H. U., Gawehn, K. \& Grassl, M. (1974). Enzymes as biochemical reagents. Glucose oxidase. In Methods of Enzymatic Analysis, 2nd edn, vol. I, pp. 457-458. Edited by H. U. Bergmeyer. New York: Academic Press.

Chistoserdova, L., Lapidus, A., Han, C., Goodwin, L., Saunders, L., Brettin, T., Tapia, R., Gilna, P., Lucas, S. \& other authors (2007). Genome of Methylobacillus flagellatus, molecular basis for obligate methylotrophy, and polyphyletic origin of methylotrophy. J Bacteriol 189, 4020-4027.

Doronina, N. V., Ivanova, E. G. \& Trotsenko, Y. A. (2005). Phylogenetic position and emended description of the genus Methylovorus. Int J Syst Evol Microbiol 55, 903-906.

Felsenstein, J. (2004). Inferring Phylogenies. Sunderland, MA: Sinauer Associates.

Giovannoni, S. J., Hayakawa, D. H., Tripp, H. J., Stingl, U., Givan, S. A., Cho, J.-C., Oh, H.-M., Kitner, J. B., Vergin, K. L. \& Rappé, M. S. (2008). The small genome of an abundant coastal ocean methylotroph. Environ Microbiol 10, 1771-1782.

Govorukhina, N. I. \& Trotsenko, Y. A. (1991). Methylovorus, a new genus of restricted facultatively methylotrophic bacteria. Int J Syst Bacteriol 41, 158-162.

Harder, W., Attwood, M. M. \& Quayle, J. R. (1973). Methanol assimilation by Hyphomicrobium sp. J Gen Microbiol 78, 155-163.

Higgins, D. G., Thompson, J. D. \& Gibson, T. J. (1996). Using CLUSTAL for multiple sequence alignments. Methods Enzymol 266, 383-402.

Jenkins, O. \& Jones, D. (1987). Taxonomic studies on some Gramnegative methylotrophic bacteria. J Gen Microbiol 133, 453-473.

Kalyuzhnaya, M. G., Lidstrom, M. E. \& Chistoserdova, L. (2004). Utility of environmental primers targeting ancient enzymes: methylotroph detection in Lake Washington. Microb Ecol 48, 463-472.

Kalyuzhnaya, M. G., Bowerman, S., Lara, J. C., Lidstrom, M. E. \& Chistoserdova, L. (2006). Methylotenera mobilis gen. nov., sp. nov., an obligately methylamine-utilizing bacterium within the family Methylophilaceae. Int J Syst Evol Microbiol 56, 2819-2823.

Kalyuzhnaya, M. G., Hristova, K. R., Lidstrom, M. E. \& Chistoserdova, L. (2008a). Characterization of a novel methanol dehydrogenase in representatives of Burkholderiales: implications for environmental detection of methylotrophy and evidence for convergent evolution. J Bacteriol 190, 3817-3823.

Kalyuzhnaya, M. G., Lapidus, A., Ivanova, N., Copeland, A. C., McHardy, A. C., Szeto, E., Salamov, A., Grigoriev, I. V., Suciu, D. \& other authors (2008b). High-resolution metagenomics targets specific functional types in complex microbial communities. Nat Biotechnol 26, 1029-1034.

Kalyuzhnaya, M. G., Martens-Habbena, W., Wang, T., Stolyar, S. M., Hackett, M., Stahl, D. A., Lidstrom, M. E. \& Chistoserdova, L. (2009). Methylophilaceae link methanol oxidation to denitrification in freshwater lake sediment as suggested by stable isotope probing and pure culture analysis. Environ Microbiol Rep 1, 385-392.

Latypova, E., Yang, S., Wang, Y. S., Wang, T., Chavkin, T. A., Hackett, M., Schäfer, H. \& Kalyuzhnaya, M. G. (2010). Genetics of the glutamate-mediated methylamine utilization pathway in the facultative methylotrophic beta-proteobacterium Methyloversatilis universalis FAM5. Mol Microbiol 75, 426-439. 
Lykidis, A., Pérez-Pantoja, D., Ledger, T., Mavromatis, K., Anderson, I. J., Ivanova, N. N., Hooper, S. D., Lapidus, A., Lucas, S. \& other authors (2010). The complete multipartite genome sequence of Cupriavidus necator JMP134, a versatile pollutant degrader. PLoS ONE 5, e9729.

Miller, J. A., Kalyuzhnaya, M. G., Noyes, E., Lara, J. C., Lidstrom, M. E.

\& Chistoserdova, L. (2005). Labrys methylaminiphilus sp. nov., a novel facultatively methylotrophic bacterium from a freshwater lake sediment. Int J Syst Evol Microbiol 55, 1247-1253.

Smibert, R. M. \& Krieg, N. R. (1994). Phenotypic characterization. In Methods for General and Molecular Bacteriology, pp. 607-654. Edited by P. Gerhardt, R. G. E. Murray, W. A. Wood \& N. R. Krieg. Washington, DC: American Society for Microbiology. 